(c) The Author(s), 2020. Published by Cambridge University Press. This is an Open Access article, distributed under the terms of the Creative Commons Attribution licence (http://creativecommons.org/licenses/by/4.0/), which permits unrestricted re-use, distribution, and reproduction in any medium, provided the original work is properly cited. doi:10.1017/S1474746420000597

\title{
The Multi-Tool Nature of Active Labour Market Policy and its Implications for Partisan Politics in Advanced Democracies
}

\section{Axel Cronert}

Department of Government, Uppsala University, Sweden and McCourt School of Public Policy, Georgetown University, USA

E-mail: axel.cronert@statsvet.uu.se

Active labour market policy (ALMP) has emerged as a major topic of inquiry among comparative scholars in recent decades, alongside other social investments. However, few conclusive results have been produced regarding the political explanations of these policies, and not least the role of partisan politics. To help remedy this problem, this article proposes a new understanding of ALMP as a profoundly versatile set of 'multi-purpose tools' that policymakers across the political spectrum can use as a means to very different distributional ends. Specifically, it highlights how ALMP programmes vary in terms of 1) their target groups, 2) their intended labour market outcomes, and 3) their modes of production in politically salient ways. Informed by the new framework and by recent research, the article then develops a refined theory about how governments with different left-right placement, operating under economic and institutional constraints, affect ALMP development in different directions.

Keywords: Active labour market policy, advanced industrial democracies, labour market transitions, partisanship, social investment.

\section{Introduction}

As recent decades have seen a growing interest in reforming advanced welfare states to promote employment, active labour market policy (ALMP) - which commonly refers to labour market training, employment subsidies, job search assistance, direct job creation programmes, etc - has emerged as a major topic of inquiry among comparative sociologists and political economists, alongside other so-called 'social investment' policies (Morel et al., 2012). A growing body of research has examined the political explanations of these policies, but few conclusive results have been produced to date. The inconclusiveness is particularly profound with respect to the role of parties on the left versus on the right in ALMP development; findings from the past decade have alternately supported theories about positive, null and negative relationships between left-wing influence and governments' ALMP 'effort'. This lack of advancements has not gone unnoticed. A group of leading scholars recently concluded that the 'process of uncovering the causal dynamics specific to this policy field is still in its infancy' and called for increased theoretical sophistication in future research on ALMP (Clasen et al., 2016: 34).

Heeding this call, this article makes a two-fold contribution to ALMP research. First, it proposes a new analytic framework that conceptualises ALMP as a profoundly versatile set of 'multi-purpose tools' that policymakers from across the political spectrum can use as a 
means to very different ends, based on the interests of their distinct constituents. Specifically, the framework highlights how ALMP programmes vary in terms of 1) their target groups, 2) their intended labour market outcomes, and 3) their modes of production. Second, informed by the framework, the article develops a fine-grained theory about how democratically elected governments with different left-right placement affect ALMP developments. Rather than having lost their relevance in the post-industrial era, it is argued, traditional ideological conflicts now find new expressions in the detailed designs of ALMP programmes. To observe these conflicts, however, scholars must move beyond routine assumptions that all ALMPs are largely equivalent.

\section{The inconclusiveness of comparative ALMP research}

While there is much scholarly disagreement about the economic and political determinants of ALMP, most analysts tend to agree that ALMPs to some extent can be viewed as a response to the pressures exerted on labour markets by the forces of deindustrialisation and globalisation (Katzenstein, 1985; Janoski, 1994; Martin and Swank, 2012; Bonoli, 2013). Also, significant congruence has been observed between the policy instruments that policymakers have introduced and the various strategies and recommendations that the EU and the OECD have adopted since the mid-1990s (Zeitlin, 2009; Weishaupt, 2011).

These two factors have contributed to a stylised understanding of ALMPs as inherently technocratic policy instruments, that are subjected to extensive scientific evaluations, diffused through policy learning processes among international networks of policymakers and experts, and rolled out as a largely functionalist solution to various clearly defined labour market challenges associated with the post-industrial economy. In this popular account, little room is left for ideologically motivated partisan conflict over ALMP among democratically elected governments, and, indeed, several studies on panel data from OECD countries have found the governments' ideological underpinnings to be unrelated to ALMP expenditure (Armingeon, 2007; Gaston and Rajaguru, 2008; Bonoli, 2013).

These results, however, are markedly at odds with those from two other scholarly camps. Most early accounts of ALMP development view these policies as a creation of the agents of the working class (Esping-Andersen and Friedland, 1982; Janoski, 1994; Rothstein, 1996; Boix, 1998). In these accounts, which may largely be seen as adhering to the 'power resources' approach, unions and social democratic governments are more inclined than employers and right-wing governments to expand ALMP, because these policies strengthen labour as an organised social force by contributing to lower levels of unemployment. The view that social-democratic influence is conducive to public spending on ALMP is also supported by a number of panel data studies (Huo et al., 2008; Iversen and Stephens, 2008; Van Vliet and Koster, 2011).

The power resources approach is challenged by Rueda (2006, 2007), who argues that recent socioeconomic transformations have split the traditional social democratic constituency into two loosely defined groups - 'insiders' and 'outsiders' - who have partly clashing interests due to their differing status on the labour market. In this account, ALMPs do not favour the already employed and well-protected insiders because, while increasing the tax burden, they promote the entry into the labour market of outsiders who can underbid insiders' wage demands. Because social democratic parties in post-industrial settings are more inclined to serve the interests of insiders - especially in cases where they 
are subjected to pressure from insider-oriented unions - these parties are unlikely to support, and might even oppose, ALMP (Rueda, 2007).

Further questioning the working-class bias of ALMPs, some have argued that these policies - particularly training programmes, labour market services, and employment subsidies - may also (or indeed primarily) benefit employers (Swenson, 2002; Farnsworth, 2012). This would suggest that right-wing governments, which have closer ties to the business community, would be more favourable toward ALMP. In support of these alternative understandings of ALMP, some studies have found a negative relationship between left-wing influence in government and public spending, on at least some categories of ALMP or at least in institutional environments where insiders have considerable influence on policy (Rueda, 2007; Vis, 2011; Tepe and Vanhuysse, 2013).

The studies referred to above have mostly treated all ALMP programmes in equivalent terms, assuming that they are all governed by a similar political logic. A more recent wave of studies has begun to acknowledge more explicitly that different categories of ALMP programmes - such as training, employment subsidies, and direct job creation programmes - have different effects on individuals and on the labour market and that, consequently, they presumably vary with respect to how different political actors value them (Bonoli, 2010; Nelson, 2013; Tepe and Vanhuysse, 2013; Vlandas, 2013). However, while they do represent a sophisticated advance within the field, the joint results from these studies on the effect of left-wing influence on ALMP expenditure are as inconclusive as those in previous literature (Cronert, 2019a).

One likely reason for the inconclusive results is the choice of dependent variable; for instance, whether or not ALMP spending is divided by the unemployment rate (see Clasen et al., 2016 for a discussion). Another plausible reason, however, is that the ample variation in the detailed design of ALMP programmes has not received sufficient attention by comparative scholars. Theoretically oriented scholars have long noted that the distributional effect of labour market policy interventions is by no means pre-defined but instead depends on their detailed design with respect to targeting, duration, content, financing, and so on (e.g. Furåker, 1976; Katz, 1998). A general takeaway from this literature is that we need to take such design variations seriously - and I argue that, if we do so, our understanding of the impact of partisanship and other political variables on ALMP development can be refined.

\section{The multi-tool nature of ALMP}

In what follows, an analytic framework is outlined, which disentangles ALMP programmes along three politically salient dimensions with clear links to traditional partisanship research: their targets, their intended labour market outcomes, and their modes of production. A good way to start the discussion about the two first dimensions is by outlining a framework of labour market statuses, between which working-age individuals may transition over the course of their lifetime. Expanding on the long-standing work of labour economists (e.g. Marston, 1976) and that of a group of political economists more recently gathered under the so-called Transitional Labour Markets (TLM) banner (Schmid, 2008; Gazier and Gautié, 2011), I propose a new framework with six statuses, as outlined in Figure 1. The point of departure for this framework is a scheme that has long served as the international standard for measurements of the population's economic activity and 


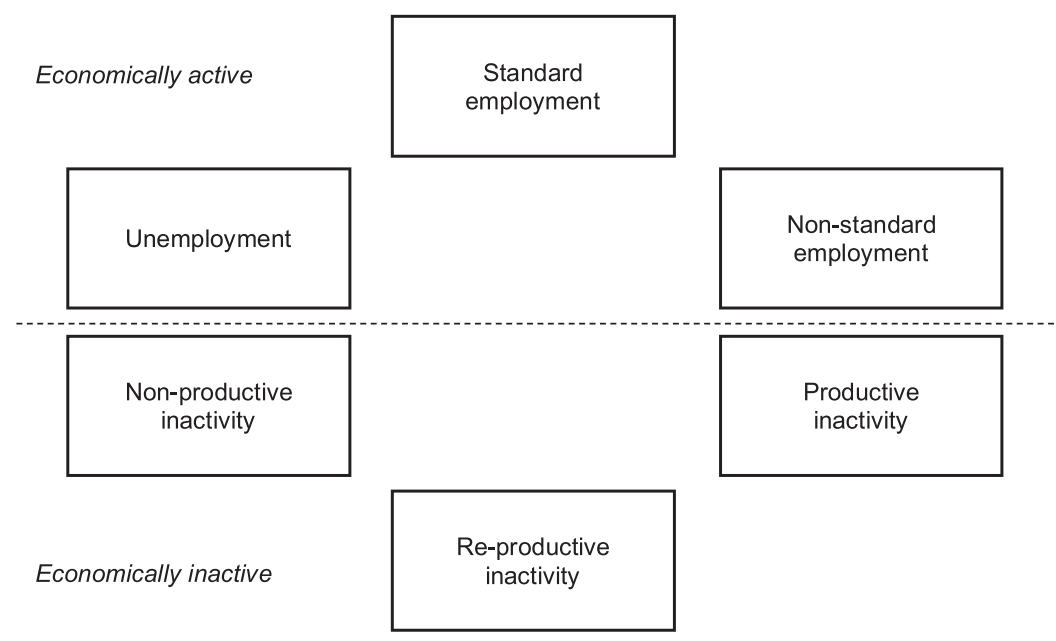

Figure 1. Six collectively exhaustive labour market statuses.

that categorises working-age individuals into three mutually exclusive and collectively exhaustive statuses: employment, unemployment, and economic inactivity (ILO, 1982).

People in employment are those who report a sufficient amount of work - typically at least one hour during a reference week - for pay, profit or family gain and those who are temporarily absent from their jobs. People in unemployment are those who are without work but who are currently available for work and seeking work. Combined, the employed and the unemployed make up what is referred to as the labour force, or, equivalently, the economically active population. The remaining population are referred to as those not in the labour force, or, equivalently, the economically inactive population. Importantly for the discussion that follows, the unemployment rate, according to international standards, refers to the number of unemployed as a share of the economically active population, whereas the employment rate typically refers to the number of employed as a share of the total population.

Yet, to fully understand the politics of ALMP we must recognise the great heterogeneity of activities included in the broad categories of employment and economic inactivity. With respect to employment, a large body of literature has identified a growing diversity of work arrangements that deviate from those of the 'standard' employment contract, including part-time or non-fixed employment, temporary contracts, self-employment, and agency work. For our present purposes, however, it should be sufficient to divide the employed into two broad categories. Therefore, let us denote full-time, permanent employment as standard employment, and label all deviations from that kind of arrangement as non-standard employment (Kalleberg, 2000).

Second, among the economically inactive population, it is useful to distinguish three groups. The first comprises those who are not currently active because of attendance at educational institutions, such as secondary, tertiary, or vocational education (ILO, 1982). Because such activities tend to increase an individual's future economic productivity, we may refer to this status as productive inactivity. A second reason for economic inactivity is engagement in household duties, including care of the home, elderly, and children (Hussmanns et al., 1990). Because of the re-productive nature of child-rearing, we may 
refer to those among the economically inactive who are involved in care of children as being in re-productive inactivity. We may refer to other homemakers, together with the remaining economically inactive population - including pensioners, rentiers, incapacitated, and youth not attending school - as persons in non-productive inactivity. This group also includes persons who are not classified as unemployed because, even though they are without work and currently available for work, they are not actively seeking work; most of these may be referred to as 'discouraged workers' (Elder, 2009).

The resulting framework includes six theoretically distinct labour market statuses, which, for our present purposes, we can think of as a set of mutually exclusive and commonly exhaustive statuses in which working-age individuals may reside and between which they may transition from one time to another in patterns that may be affected by ALMPs (as well as other policies).

Given the productive nature of education, a last useful distinction could be added to the framework in Figure 1, whereby the two employment categories together with the productive inactivity category are referred to as growth-enhancing, or productive, labour market statuses, and the remaining three are referred to as non-productive.

\section{Three disputed dimensions of ALMP design}

We may now theoretically define ALMP in relation to this framework as follows: Active labour market policies are public interventions in the labour market aimed at promoting individuals' transition to, or retention in, productive labour market statuses, which can be distinguished from other general employment policy interventions in that they act selectively to support people who are unemployed, economically inactive, or employed and at risk of losing their jobs. This definition harmonises well with the operational definition of ALMP that guides data collection on labour market policy measures by the European Commission (2018) and the OECD (2018), which should make it useful in most cross-national applications.

\section{Targeting}

The framework presented above can be used to understand two sources of variation in ALMP design, the first of which concerns programmes' targeting. In line with Rueda's (2006) influential claim that ALMPs unambiguously benefit outsiders, comparative research on ALMP has largely neglected that ALMP programmes may actually be targeted very differently. Indeed, programmes may target any combination of groups in the six labour market statuses discussed above. Usefully, the programme-level EU LMP Database (European Commission, 2015) contains indicators on whether a programme targets people in employment, unemployment, and/or economic inactivity, respectively, which can illustrate this point.

For all labour market measures in the EU-27 and Norway between 1998 and 2013, the Venn diagram in Figure 2 shows the percentage of programmes within each of the possible combinations of the three target groups (with the percentages summing to 100). For almost nine out of ten programmes, the target group includes people who are registered unemployed. Perhaps more surprisingly, nearly one in four programmes target people who are employed but at risk of losing their jobs. Examples include so-called shorttime work programmes that many European governments rolled out during the financial 


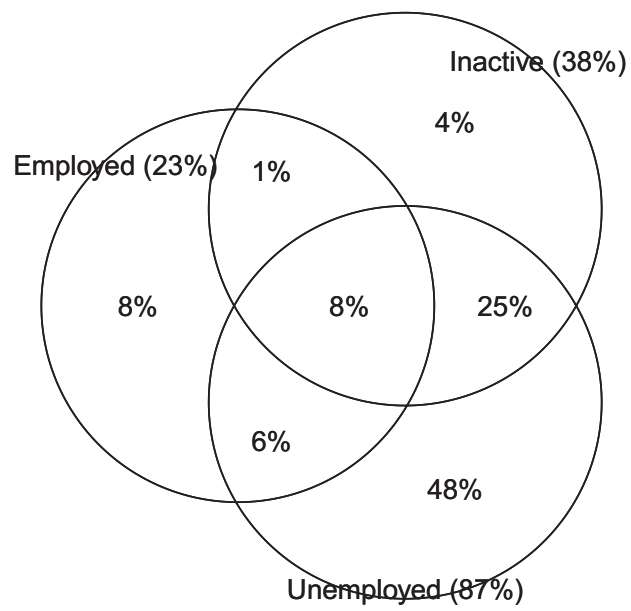

Figure 2. Venn diagram of target groups of ALMP programmes in the EU-27 and Norway, 1998-2013. Based on 9,180 programme-year observations. Percentages sum to 100.

crisis as well as the COVID-19 crisis to subsidise work time reduction and training for workers who would otherwise run the risk of dismissal, and programmes that serve to sustain the employment of workers with reduced working capacity.

Figure 2 furthermore shows that, for four out of ten programmes, the target group includes people in inactivity. A case in point here is the recruitment subsidy Nystartsjobb established in Sweden in 2007. Eligible participants include not only the registered unemployed but anyone who has been out of employment for a long time (typically for more than one year) or who is a newly arrived immigrant (European Commission, 2015).

Although, as evidenced by Figure 2, most programmes for people in inactivity also cover other target groups, 4 percent of them exclusively target narrower groups. Recent examples include a programme in Italy that provides tax incentives for the employment of people in custody or in prison (Inserimento lavorativo dei detenuti) and two German programmes that provide means-tested support to youth with economic or social disadvantages to help them complete vocational training (Berufsausbildungsbeihilfe and Ausbildungsbegleitende Hilfen).

The targeting dimension may be useful for understanding how ALMP programmes are treated politically. For instance, how programmes are targeted tends to be related to how much resources are devoted to them and how vulnerable they are to termination. Two examples of this are found in Cronert (2019b), which examines the design and outcomes of employment subsidy programmes across Europe. First, programmes that specifically serve to maintain the employment of workers with disabilities tend to be nearly three times as generous and considerably less vulnerable to termination than other programmes. Second, among the more short-lived programmes which tend to be rolled out to counteract temporary labour demand shortages during economic downturns, subsidies that specifically target 'insiders' - such as the aforementioned short-time work programmes - are, on average, allocated 50 percent more spending per participant than programmes that are more broadly targeted at people in unemployment and inactivity. 
The importance of considering the target group of ALMP programmes becomes even clearer if we bear in mind that any positive effect a programme potentially has on its target group may come to the detriment of people outside the target group. Such equilibrium effects may appear, for instance, if a job search assistance programme or an employment subsidy programme increases the employment prospects for its participants but at the same time makes it more difficult for non-participants to find or retain a job (Crépon and van den Berg, 2016).

\section{Intended labour market outcomes}

A second source of variation in ALMP programmes is the intended labour market outcome of the participation, or, to put it in relation to the framework in Figure 1, the labour market status(es) to which the participant is intended to go during or after his or her participation. Naturally, the objective of most programmes is to enable participants to enter, or remain in, employment. In practice, however, programmes are more or less specific about the intended destination. The short-time work programmes, for instance, are specifically oriented toward employment, as they serve to prevent workers from flowing out of employment into unemployment or inactivity. Similarly, employment subsidy programmes typically involve the establishment of a formal employment contract, which typically means that the participant's unemployment spell is broken or suspended and that his or her labour market status is automatically switched from unemployment to employment - at least for the duration of the programme. Another possible switch of status, mostly relevant for training programmes, is from unemployment to productive inactivity (i.e. education).

Some employment subsidies are intended specifically to promote standard employment. A case in point is the so-called 'star contract' introduced in Spain in 1997. This programme grants employers a 40-60 percent reduction in social security contributions during the first two years of employment in return for signing a permanent contract with a disadvantaged worker (Tompson and Price, 2009). Other programmes are much less definite about the intended destination of participants. Examples include so-called 'work first' programmes aimed at unemployed and inactive individuals to initiate or increase job search activity, often as a requirement for maintaining cash benefits. Compared to training programmes and private sector employment subsidy programmes, 'work first' programmes tend to channel people into non-subsidised employment more quickly, but their long-term effects on employment and earnings tend to be more limited (Card et al., 2018). Expressed in relation to Figure 1, 'work first' programmes are more likely than others to channel people into non-standard employment.

Here, it may be noted that to the extent that job search assistance and similar programmes target people in inactivity, and yet these participants fail to find a job, programme participation may result in a transition from inactivity to unemployment. This implies that some ALMP programmes might, counter-intuitively, increase the unemployment rate. Another important factor in this context is the definition of a suitable employment offer: that is, specifying which occupations, wage levels, and working conditions a benefit recipient has to accept in order to avoid being sanctioned (Knotz, 2018). The stricter these requirements, the more likely it is that people will transition from unemployment or inactivity to non-standard employment. 


\section{Modes of production}

A third key dimension of variation has to do with the involvement of different actors in the organisation and the implementation of ALMP. A first question is who is responsible for administration and delivery of the publicly mandated interventions (Bredgaard and Larsen, 2008; van Berkel and Borghi, 2008). As elaborated by Weishaupt (2011), this responsibility may be divided among multiple levels of government; it may be shared with employers and unions through their involvement in management or supervision; and it may be delegated to various external providers, for-profit or not-for-profit, under various types of quasi-market arrangements.

A 2014 European Commission survey reveals that no one organisational model dominates among the European countries. In some countries, the Public Employment Service (PES) is part of a ministry (e.g. Ireland and the United Kingdom) or a government executive agency (e.g. Hungary and Sweden), with little or no involvement of employers and unions. In other countries (e.g. Austria, Belgium and France), the PES is an autonomous public body governed with the direct participation of the social partners. With respect to private providers, virtually all PESs report that they outsource training to municipalities or private organisations, whereas in only a few cases (e.g. Sweden and the United Kingdom) are private providers involved in the complete case-management process (Manoudi et al., 2014). Australia and New Zealand are two notable cases where public services have been fully outsourced to private, for-profit agencies (Weishaupt, 2011).

In an analysis of PES reforms across Western Europe, Weishaupt (2010) shows that the lack of agreement on a 'best-practice' model for the organisation of ALMP delivery despite the widespread diffusion of New Public Management ideas - is at least partly due to the highly political nature of public sector reform, which makes such reforms conditional on the outcomes of struggles between powerful actors. In short, Weishaupt found PES reforms to be characterised by 'politics as usual' (2010: 480). Importantly, who is involved in managing labour market programmes may matter for which programmes are put in place. For instance, it has been found that involvement of unions and employers in the administration of the PES is conducive to the introduction of short-time work programmes (Weishaupt, 2013). Generally, the distributional profiles of these programmes differ from those of most others in the sense that they target comparably well-established workers and that they specifically benefit employers by making it easier for them to retain skills during economic downturns (Thelen, 2014).

A second organisational matter concerns the participation of employers and unions in the actual production of programmes (Bredgaard, 2018). As elaborated by Cronert (2018), some types of ALMP programmes can be produced unilaterally by the state through the PES and its sub-contracted service providers. Institutional training programmes arranged at a school or a training centre, job search assistance programmes, sheltered employment programmes for the disabled, programmes for direct job creation in the public sector, and start-up incentives are examples of such programmes. In contrast, recruitment subsidies, apprenticeships and similar programmes that are partly or fully located at the workplace can only be produced jointly by the state and employers, to the extent that employers are willing to provide the required resources: that is, employment opportunities or access to work facilities and supervision. Typically, in these types of programmes, a client is assessed by a caseworker and referred to a suitable position with an employer who 
agrees - sometimes after mandatory consultation with a union or a work council - to take on that specific client. In exchange, the employer receives a benefit from the state, typically cash payments or exemptions from obligatory social contributions.

\section{A theory of constrained partisanship and ALMP}

This section outlines a refined theory about the role of partisanship for ALMP and applies it to the framework above. The arguments draw on long-standing research showing how distinct preferences of political parties affect the design of economic policy and public service delivery. Yet, it extends these discussions by applying them to the multi-dimensional conception of ALMP outlined above and by considering a number of important constraints under which governments in advanced democracies operate (Gingrich, 2011; Beramendi et al., 2015).

In line with most previous work, I suggest that the primary conflicts shaping ALMP stand between parties on the left (i.e. social democratic parties, other left parties, and most green parties) and on the right (i.e. liberal and conservative parties) or the centre-right (e.g. Christian democratic parties) of the political spectrum. Although the policy preferences of these two 'families' are by no means constant across time or space, parties at the respective side of the spectrum are related to each other by their similar core ideological stances, which are in turn linked to their specific core constituencies. Notwithstanding a gradual reconfiguration of the electoral constituencies of the parties on the left in recent decades, whereby traditional working-class voters have been partly substituted by middleclass voters with occupational ties to the public sector (Gingrich and Häusermann, 2015), these parties (still) typically derive a larger share of their support from voters who are relatively lacking in (all sorts of) assets, including secure employment (Marx, 2014; Rovny and Rovny, 2017). They also tend to have stronger ties to trade unions than parties on the right - some Christian democratic parties aside (Kalyvas and van Kersbergen, 2010). Parties on the right, by contrast, tend to attract the vote primarily from workers with higher qualifications and more secure employment, and from people who are asset holders, including the business community (Boix, 1998; Marx, 2014; Rovny and Rovny, 2017); even though recently support for these parties among traditionally more left-leaning voters has grown in several countries (Gingrich and Häusermann, 2015). Also, more often the parties on the right have cultivated a close relationship with employers and their associations (Cioffi and Höpner, 2006).

While the distinct characteristics of parties on the left and right translate into some rather different distributional preferences, parties also have some crucial preferences in common. Most importantly, first and foremost, all major parties on both sides prefer economic policy that maximises economic growth. Growth tends to increase the electoral strength of incumbent governments by raising the disposable income of their constituents and of other prospective voters; thus, it serves as an 'unavoidable requirement' to be met by any major vote-seeking party (Boix, 1998: 5). In the second place, governments make distinctive economic policy choices depending on their expected distributional outcomes. Below, I argue that, with respect to ALMP, the key partisan divides concern parties' preferences for unemployment, and for the involvement of non-state actors in policy production.

However, while political parties are the key actors driving ALMP reform, their policy choices are not made in an unconstrained world. Any government entering into office in 
an advanced industrial democracy inherits a sizable portfolio of policy programmes, each of which has a specific legacy and a specific group of supporters who exert active or latent pressures that policymakers have to navigate alongside those from other stakeholders (Pierson, 1993; Häusermann et al., 2013). In the case of ALMP, the support coalition is not necessarily limited to, nor does it even primarily consist of, those who are in the programme's target groups. As argued by Bonoli (2013), people who view themselves as net contributors to social security systems, including employers and better-off workers, oftentimes view ALMP programmes as win-win solutions to social problems, since they may improve the well-being of their target groups while reducing reliance on publicly funded transfer programmes. Such attitudes among the public might be part of the explanation of the resilience of ALMP (Garritzmann et al., 2018). At the same time, because the majority of voters will rarely, if ever, be personally affected by these interventions, most of them reasonably have little stake in their detailed settings, leaving politicians a certain room for manoeuvre.

Second, the decisions politicians make are likely to be influenced by structural and cyclical pressures from the real economy. The general decline of manufacturing employment and the increasing international competition in the wake of globalisation are often viewed as drivers of public expenditure on ALMP (Katzenstein, 1985; Janoski, 1994; Bonoli, 2013). Similarly, during recessions, when unemployment and inactivity rates rise, demand for labour market interventions tend to increase (Huber and Stephens, 2001).

Third, politicians are likely to be influenced by policy experts in the domestic and international bureaucracies. Notably, there is compelling evidence that technocrats at the European Commission and the OECD have played a major role in defining and consolidating the set of economic policy instruments that are available for consideration by contemporary policymakers, not least in the field of ALMP (Zeitlin, 2009; López-Santana, 2006; Weishaupt, 2010, 2011). Nevertheless, the extent to which policy experts constrain politicians must not be overestimated. As observed by López-Santana (2006: 494) with respect to ALMP, domestic policy-makers can still 'maneuver within the multiple policy configurations' that are promoted internationally and subsequently design policies in very different ways.

Thus, despite pressures from the electorate, the economy and the experts, politicians do have some scope to design ALMP differently according to partisan considerations. Because of their different preferences for unemployment and for the involvement of nonstate actors in policy production, they tend to make different trade-offs with respect to the three dimensions.

\section{Targeting}

For two reasons, the primary partisan conflict regarding targeting derives from parties on the left having a stronger aversion to unemployment than parties on the right. First, the core constituents of the left are overrepresented among the losers of unemployment, because it disproportionally affects workers at the low end of the labour market and because it weakens the bargaining position of unions vis-à-vis that of employers (Hibbs, 1977). Second, due to issue ownership, left-wing governments are often found to be penalised particularly harshly for unemployment by the voters (e.g. Van der Brug et al., 2007). Drawing on the work of Furåker (1976), Cronert (2019a) argues, and finds, that leftwing governments in Europe are more inclined than right-wing governments to expand 
programmes exclusively targeted at the unemployed and/or the employed at risk of dismissal, because these programmes are more likely intended specifically to reduce or prevent unemployment. In contrast, programmes that are targeted also, or exclusively, at people in inactivity can be expected to be less subjected to partisan conflict, because they serve, also or exclusively, to increase labour supply by making otherwise inactive people take up work or at least begin searching. If such programmes succeed, growth might increase both directly, through increased output, and indirectly, if the new employment mitigates bottlenecks caused by labour shortages. Moreover, these programmes might have side effects, such as increased tax revenue and lower caseloads in other more expensive social security programmes, which are attractive to all governments, irrespective of their ideologies or allegiances.

Importantly, these findings reconcile the diverging assumptions in the 'power resources' and 'insider/outsider' approaches about ALMP, by showing that programmes can be used both to strengthen the position of organised labour by reducing or preventing unemployment, and to promote the entry of 'outsiders' into employment. These findings are also consistent with a related argument by Gingrich and Ansell (2015) that right-wing governments are more inclined to increase public spending on ALMP in those specific institutional contexts where such spending is more likely to target individuals outside the labour force.

\section{Intended labour market outcomes}

Given the political salience of working arrangements, employment levels and unemployment levels, there are reasons to expect that the second design dimension also accommodates considerable partisan conflict. First, given that governments relatively easily may - and do, as exemplified by Sengenberger (2011: 84) - adjust programme settings so as to mechanically alter formal unemployment rates, these settings should be important for understanding labour market policy-making as well as, possibly, the outcomes of these policies. ${ }^{1}$ Cronert (2019a) approaches this question by testing if left-wing governments are more prone than right-wing governments to expand programmes that, other things being equal, break the unemployment spell. In line with theory, left-wing influence is found to be positively associated with the size of such programmes, but unrelated to the size of programmes that serve to maintain participants' labour supply.

Second, parties tend to differ in their views of what constitutes acceptable employment conditions. In a recent study of party positions on non-standard employment in four countries with high incidence (Germany, France, Italy, and Spain), Picot and Menéndez (2019) found that these positions follow a left-right distribution. Parties on the left (especially left-libertarian parties) are more vocal proponents of diminishing the gap between standard and non-standard forms of employment, whereas parties on the right with occasional exceptions for Christian democratic parties - are less so. In that vein, a hypothesis for future research is that left-wing parties have a stronger aversion to ALMP programmes that are more likely to channel participants into non-standard employment.

\section{Modes of production}

Finally, there is a partisan component in the choice of the mode of production of ALMP programmes. First, drawing on the aforementioned distinction between unilaterally and 
Table 1 Summary of expected partisan preferences on three dimensions of ALMP design

\begin{tabular}{|c|c|c|}
\hline & Left parties & Right parties \\
\hline Targeting & $\begin{array}{l}\text { Broader targeting, including also } \\
\text { the unemployed and employed at } \\
\text { risk ('insiders') }\end{array}$ & $\begin{array}{l}\text { Narrower targeting, focusing on the } \\
\text { economically inactive ('outsiders') }\end{array}$ \\
\hline $\begin{array}{l}\text { Intended } \\
\text { labour } \\
\text { market } \\
\text { outcomes }\end{array}$ & $\begin{array}{l}\text { Stronger preference for standard } \\
\text { employment }\end{array}$ & $\begin{array}{l}\text { More permissive of non-standard } \\
\text { employment and unemployment }\end{array}$ \\
\hline $\begin{array}{l}\text { Modes of } \\
\text { production }\end{array}$ & $\begin{array}{l}\text { More supportive of unilateral } \\
\text { production by the state }\end{array}$ & $\begin{array}{l}\text { Stronger preference for joint } \\
\text { production, contracting out of } \\
\text { delivery, and quasi-market models }\end{array}$ \\
\hline
\end{tabular}

jointly produced programmes, I argue that the latter type is particularly likely to bring substantial economic benefits to firms in return for their involvement. Employment subsidy programmes, for instance, oftentimes reduce wage costs for hired workers by as much as 60-80 percent and employers tend to prefer them to unilateral programmes (Cronert, 2018).

Consequently, because employers generally have closer ties to the right, these parties tend to have stronger incentives than those on the left to prefer joint programmes to unilateral programmes. Moreover, involving non-state producers in the production of social services is a way for the right to reduce the role of the state and strengthen private interests that typically support right-wing policy (Gingrich, 2011). For the left, in contrast, we may expect that the mode of production is less salient. On the one hand, joint programmes are generally found to be slightly more effective than most unilateral programmes (Card et al., 2018); on the other hand, the left may view unilateral provision as a strategy to sustain support for public services by tying participants (as well as caseworkers) to the public sector (cf. Gingrich, 2011).

Second, a similar argument applies to the outsourcing of labour market service delivery to private firms and, relatedly, to the use of quasi-market models; while left parties might want to contract out delivery in an effort to maintain the legitimacy of the welfare state among middle-class constituencies, they should be more reluctant privatisers than right parties (Zehavi, 2012).

Recent examples from Sweden and the United Kingdom, studied in Cronert (2018), illustrate how these conflicts may play out. In Sweden, the Confederation of Swedish Enterprise and the Conservative party recently emerged as the most vocal defenders of the extensive employment subsidy programme Nystartsjobb when the left-wing coalition government announced tightening in 2015. In the United Kingdom in 2009, the Labour government introduced the Future Jobs Fund - a large job creation programme targeted primarily at the public sector - as part of its response to the financial crisis. The fund, however, was terminated shortly after a new centre-right coalition government assumed office in 2010 and was replaced by the smaller Work Programme, in which contracted 
labour market service providers - predominantly from the private sector - deliver services to jobless clients under a 'black box' commissioning model that grants providers ample discretion as to how services are produced. Additional analyses of time-series-crosssection data from twenty-one OECD countries show that, on average, partisanship is related to how ALMP spending is divided between joint programmes and unilateral programmes, yet is unrelated to the total level of spending.

Summarising the refined theory, Table 1 presents the expected preferences regarding the three dimensions of ALMP design for parties on the left and the right respectively. Centre-right Christian democratic parties can be expected to fall somewhere between, as they are usually somewhat more supportive of measures favouring employed insiders (Rueda, 2005), less positive of non-standard employment relations (Picot and Menéndez, 2019) and less oriented towards the private sector in ALMP production (Bonoli, 2010) than conservative and liberal parties.

\section{Concluding remarks}

Active labour market policies are more versatile than commonly recognised among comparative scholars. Indeed, they might best be conceived of as multi-purpose tools of sorts, which policymakers may use as a means to rather different distributional ends. Key to understanding the politics of ALMP, thus, is to pay more attention to the ample variation in the detailed design of these programmes (for a related argument, applied to the welfare state as a whole, see e.g. Jensen, 2012). Specifically, to better understand the disputed role of partisan politics in the policy field, scholars will do well to consider programmes' varying target groups, intended labour market outcomes, and modes of production rather than treating all ALMP programmes in equivalent terms. That way, one may observe more detailed patterns that can reconcile some conflicting findings based on overly general contradictory assumptions: for instance, about who benefits from ALMPs in the 'power resources' and 'insider/outsider' approaches, or about the distributional effects of employment subsidies in Nelson (2013) and Vlandas (2013).

For quantitative research, this requires shifting from analyses of aggregate indicators on ALMP spending to theoretically founded comparisons of disaggregated groups of programmes. The detailed data on individual programmes' design, expenditures and participants in the EU LMP Database appear particularly useful to that end, as they allow for flexible categorisations of programmes (for recent applications, also involving participant data, see Cronert 2019a, 2019b, Fredriksson, 2020).

While the framework proposed here focuses on three design dimensions with clear links to traditional partisanship research, programmes evidently vary also in other important respects. For instance, distinctions based on the human capital investment content clearly figure more prominently in previous typologies of ALMP programmes (e.g. Bonoli, 2010). However, the extent to which this distinction should matter for the politics of ALMP is less clear. Some scholars view training programmes as distinctly leftist interventions because of their supposed equality-enhancing effects (Boix, 1998), while others argue that training programmes might rather be of most interest to businesses (Swenson, 2002; Farnsworth, 2012). In my view, a tentative hypothesis for future research is that the human capital investment content of ALMP is determined more by non-partisan assessments of the needs of the target groups and of their prospective employers and is 
thus likely to be driven less by partisanship and more by factors related to demography and industry (see Vlandas, 2013).

Furthermore, analysing how ALMP programmes are financed is likely important for fully understanding both their distributional properties and political salience. For example, what portions of ALMP expenditure are financed by general government funds, social security funds, and resources from the European Social Fund (ESF) vary across countries (Manoudi et al., 2014). Such differences reasonably affect how, among actors, the redistribution of ALMP resources actually takes place, and they also likely affect the room for governments to manoeuvre.

Lastly, further research is also needed regarding the role played by networks of national and international experts in shaping policy priorities and designs. As shown by Zeitlin (2009), Weishaupt (2011) and others, processes of social learning and 'puzzling' in such networks appear to have contributed to shifts in policy orientation and thinking among national policymakers and to have triggered ALMP reforms across the EU and OECD. Still, the key argument in this article is that the process of 'puzzling', however important for establishing ALMP as an accepted part of contemporary governments' toolbox, has not crowded out the opportunity for 'powering' on the part of democratically elected politicians and other political actors with conflicting interests (cf. Heclo, 1974). Exploring how the two types of processes interact appears as a promising endeavour for future research on ALMP - not least for analyses of the massive resources that many governments began devoting to short-time work and other ALMP programmes in response to the COVID-19 outbreak in early 2020 (ILO, 2020).

\section{Acknowledgements}

The author is grateful for helpful comments by the editors, three anonymous referees, and participants at a research seminar at the Swedish Confederation of Professional Employees (TCO) in Stockholm, August 2019. Funding from the Uppsala Center for Labor Studies is gratefully acknowledged.

\section{Note}

1 As noted by Sengenberger (2011: 85), such artificially created differences 'impair not only the comparability of national unemployment rates but also that of the internationally standardized rates because they likely affect respondents' replies in household surveys'.

\section{References}

Armingeon, K. (2007) 'Active labour market policy, international organizations and domestic politics', Journal of European Public Policy, 14, 6, 905-32.

Beramendi, P., Häusermann, S., Kitschelt, H. and Kriesi, H. (2015) The Politics of Advanced Capitalism, Cambridge: Cambridge University Press.

Boix, C. (1998) Political Parties, Growth and Equality: Conservative and Social Democratic Economic Strategies in the World Economy, Cambridge: Cambridge University Press.

Bonoli, G. (2010) 'The political economy of active labor-market policy', Politics and Society, 38, 4, 435-57.

Bonoli, G. (2013) The Origins of Active Social Policy: Labour Market and Childcare Policies in a Comparative Perspective, Oxford: Oxford University Press. 
Bredgaard, T. (2018) 'Employers and active labour market policies: typologies and evidence', Social Policy and Society, 17, 3, 365-77.

Bredgaard, T. and Larsen, F. (2008) 'Quasi-markets in employment policy: do they deliver on promises?', Social Policy and Society, 7, 3, 341-52.

Card, D., Kluve, J. and Weber, A. (2018) 'What works? A meta analysis of recent active labor market program evaluations', Journal of the European Economic Association, 16, 3, 894-931.

Cioffi, J. W. and Höpner, M. (2006) 'The political paradox of finance capitalism: interests, preferences, and center-left party politics in corporate governance reform', Politics and Society, 34, 4, 463-502.

Clasen, J., Clegg, D. and Goerne, A. (2016) 'Comparative social policy analysis and active labour market policy: putting quality before quantity', Journal of Social Policy, 45, 1, 21-38.

Crépon, B. and van den Berg, G. J. (2016) 'Active labor market policies', Annual Review of Economics, 8, 521-46.

Cronert, A. (2018) 'Accommodation or extraction? Employers, the state, and the joint production of active labor market policy', Politics and Society, 46, 4, 539-69.

Cronert, A. (2019a) 'Unemployment reduction or labor force expansion? How partisanship matters for the design of active labor market policy in Europe', Socio-Economic Review, 17, 4, 921-46.

Cronert, A. (2019b) 'Varieties of employment subsidy design: theory and evidence from across Europe', Journal of Social Policy, 48, 4, 839-59.

Elder, S. (2009) ILO School-to-work Transition Survey: A Methodological Guide. Module 4: Key Indicators of Youth Labour Markets: Concepts, Definitions and Tabulations, Geneva: ILO.

Esping-Andersen, G. and Friedland, R. (1982) 'Class coalitions in the making of West European economies', Political Power and Social Theory 3, 1, 1-52.

European Commission (2015) Labour Market Policy (Source: DG EMPL) (Imp). Reference Metadata in Euro SDMX Metadata Structure (ESMS), https://ec.europa.eu/employment_social/employment_analysis/ Imp/lmp_esms.htm [accessed 25.05.2020].

European Commission (2018) Labour Market Policy Statistics: Methodology 2018, Luxembourg: Publications Office of the European Union.

Farnsworth, K. (2012) Social Versus Corporate Welfare, Basingstoke: Palgrave Macmillan.

Fredriksson, D. (2020) 'Moving targets: target groups of active labour market policies and transitions to employment in Europe', International Journal of Social Welfare, doi: 10.1111/ijsw.12421.

Furåker, B. (1976) Stat och Arbetsmarknad: Studier i Svensk Rörlighetspolitik [State and Labour Market: Studies in Swedish Mobility Politics], Lund: Arkiv.

Garritzmann, J. L., Busemeyer, M. R. and Neimanns, E. (2018) 'Public demand for social investment: new supporting coalitions for welfare state reform in Western Europe?', Journal of European Public Policy, $25,6,844-61$.

Gaston, N. and Rajaguru, G. (2008) 'The rise (and fall) of labour market programmes: domestic vs. global factors', Oxford Economic Papers, 60, 4, 619-48.

Gazier, B. and Gautié, J. (2011) 'The "Transitional Labour Markets" approach: theory, history and future research agenda', Journal of Economic and Social Policy, 14, 1, 6.

Gingrich, J. (2011) Making Markets in the Welfare State: The Politics of Varying Market Reforms, Cambridge: Cambridge University Press.

Gingrich, J. and Ansell, B. W. (2015) 'The dynamics of social investment: human capital, activation, and care', in P. Beramendi, S. Häusermann, H. Kitschelt and H. Kriesi (eds.), The Politics of Advanced Capitalism, Cambridge: Cambridge University Press, 282-304.

Gingrich, J. and Häusermann, S. (2015) 'The decline of the working-class vote, the reconfiguration of the welfare support coalition and consequences for the welfare state', Journal of European Social Policy, $25,1,50-75$.

Heclo, H. (1974) Modern Social Politics in Britain and Sweden, New Haven: Yale University Press.

Hibbs, D. A. (1977) 'Political parties and macroeconomic policy', American Political Science Review, 71, 4, 1467-87. 
Huber, E. and Stephens, J. D. (2001) Development and Crisis of the Welfare state: Parties and Policies in Global Markets, Chicago: University of Chicago Press.

Huo, J., Nelson, M. and Stephens, J. D. (2008) 'Decommodification and activation in social democratic policy: resolving the paradox', Journal of European Social Policy, 18, 1, 5-20.

Hussmanns, R., Mehran, F. and Verma V. (1990) Surveys of Economically Active Population, Employment, Unemployment and Underemployment: An ILO Manual on Concepts and Methods, Geneva: ILO.

Häusermann, S., Picot, G. and Geering, D. (2013) 'Rethinking party politics and the welfare state - Recent advances in the literature', British Journal of Political Science, 43, 1, 221-40.

ILO (1982) Resolution Concerning Statistics of the Economically Active Population, Employment, Unemployment and Underemployment, Adopted by the Thirteenth International Conference of Labour Statisticians (October 1982), Geneva: ILO.

ILO (2020) COVID-19 and the World of Work: Country Policy Responses, https://www.ilo.org/global/ topics/coronavirus/country-responses/lang-en/index.htm [accessed 19.05.2020].

Iversen, T. and Stephens, J. D. (2008) 'Partisan politics, the welfare state, and three worlds of human capital formation', Comparative Political Studies, 41, 4-5, 600-37.

Janoski, T. (1994) 'Direct state intervention in the labor market: the explanation of active labor market policy from 1950 to 1988 in social democratic, conservative and liberal regimes', in T. Janoski and A. Hicks (eds.), The Comparative Political Economy of the Welfare State, New York: Cambridge University Press, 54-92.

Jensen, C. (2012) 'Labour market- versus life course-related social policies: understanding cross-programme differences', Journal of European Public Policy, 19, 2, 275-91.

Kalleberg, A. L. (2000) 'Nonstandard employment relations: part-time, temporary and contract work', Annual Review of Sociology, 26, 1, 341-65.

Kalyvas, S. and van Kersbergen, K. (2010) 'Christian democracy', Annual Review of Political Science, 13, 183-209.

Katz, L. F. (1998) 'Wage subsidies for the disadvantaged', in R. B. Freeman and P. Gottschalk (eds.), Generating Jobs: How to Increase Demand for Less-skilled Workers, New York: Russell Sage Foundation, 21-53.

Katzenstein, P. (1985) Small States in World Markets: Industrial Policy in Europe, Ithaca: Cornell University Press.

Knotz, C. (2018) 'A rising workfare state? Unemployment benefit conditionality in 21 OECD countries, 1980-2012', Journal of International and Comparative Social Policy, 34, 2, 91-108.

López-Santana, M. (2006) 'The domestic implications of European soft law: framing and transmitting change in employment policy', Journal of European Public Policy, 13, 4, 481-99.

Manoudi, A., Nevala-Hall, A. M., Scharle, A., Csillag, M., Metcalfe, H., Duchemin, C. and Maillart, I. (2014) Small Scale Study on PES Business Models, Brussels: European Commission.

Marston, S. T. (1976) 'Employment instability and high unemployment rates', Brookings Papers on Economic Activity, 1976, 1, 169-210.

Martin, C. J. and Swank, D. (2012) The Political Construction of Business Interests: Coordination, Growth, and Equality, Cambridge: Cambridge University Press.

Marx, P. (2014) 'Labour market risks and political preferences: the case of temporary employment', European Journal of Political Research, 53, 1, 136-59.

Morel, N., Palier, B. and Palme, J. (2012) Towards a Social Investment Welfare State? Ideas, Policies and Challenges, Bristol: Policy Press.

Nelson, M. (2013) 'Making markets with active labor market policies: the influence of political parties, welfare state regimes, and economic change on spending on different types of policies', European Political Science Review, 5, 2, 255-77.

OECD (2018) The Scope and Comparability of Data on Labour Market Programmes, https://www.oecd.org/ employment/emp/ALMPdata-Scope-and-Comparability.pdf [accessed 25.05.2020].

Picot, G. and Menéndez, I. (2019) 'Political parties and non-standard employment: an analysis of France, Germany, Italy and Spain', Socio-Economic Review, 14, 4, 899-919. 
Pierson, P. (1993) 'When effect becomes cause: policy feedback and political change', World Politics, 45, 4, 595-628.

Rothstein, B. (1996) The Social Democratic State: The Swedish Model and the Bureaucratic Problem of Social Reforms, Pittsburgh: University of Pittsburgh Press.

Rovny, A. E. and Rovny, J. (2017) 'Outsiders at the ballot box: operationalizations and political consequences of the insider-outsider dualism', Socio-Economic Review, 15, 1, 161-85.

Rueda, D. (2005) 'Insider-outsider politics in industrialized democracies: the challenge to Social democratic parties', American Political Science Review, 99, 1, 61-74.

Rueda, D. (2006) 'Social democracy and active labour-market policies: insiders, outsiders and the politics of employment promotion', British Journal of Political Science, 36, 3, 385-406.

Rueda, D. (2007) Social Democracy Inside Out: Partisanship and Labor Market Policy in Industrialized Democracies, Oxford: Oxford University Press.

Schmid, G. (2008) Full Employment in Europe: Managing Labour Market Transitions and Risks, Cheltenham: Edward Elgar Publishing.

Sengenberger, W. (2011) Beyond the Measurement of Unemployment and Under-Employment: The Case for Extending and Amending Labour Market Statistics, Geneva: ILO.

Swenson, P. A. (2002) Capitalists Against Markets: The Making of Labor Markets and Welfare States in the United States and Sweden, New York: Oxford University Press.

Tepe, M. and Vanhuysse, P. (2013) 'Parties, unions and activation strategies: the context-dependent politics of active labour market policy spending', Political Studies, 61, 3, 480-504.

Thelen, K. (2014) Varieties of Liberalization and the New Politics of Social Solidarity, New York: Cambridge University Press.

Tompson, W. and Price, R. (2009) The Political Economy of Reform: Lessons from Pensions, Product Markets and Labour Markets in Ten OECD countries, Paris: OECD Publishing.

Van Berkel, R. and Borghi, V. (2008) 'Review article: the governance of activation', Social Policy and Society, 7, 3, 393-402.

Van der Brug, W., Van der Eijk, C. and Franklin, M. (2007) The Economy and the Vote: Economic Conditions and Elections in Fifteen Countries, Cambridge: Cambridge University Press.

Van Vliet, O. and Koster, F. (2011) 'Europeanization and the political economy of active labour market policies', European Union Politics, 12, 2, 217-39.

Vis, B. (2011) 'Under which conditions does spending on active labor market policies increase? An fsQCA analysis of 53 governments between 1985 and 2003', European Political Science Review, 3, 2, 229-52.

Vlandas, T. (2013) 'Mixing apples with oranges? Partisanship and active labour market policies in Europe', Journal of European Social Policy, 23, 1, 3-20.

Weishaupt, T. J. (2010) 'A silent revolution? New management ideas and the reinvention of European public employment services', Socio-Economic Review, 8, 3, 461-86.

Weishaupt, T. J. (2011) From the Manpower Revolution to the Activation Paradigm: Explaining Institutional Continuity and Change in an Integrating Europe, Amsterdam: Amsterdam University Press.

Weishaupt, T. J. (2013) 'Governing public employment services: new public management, social partnership and privatization', in J. Heyes and L. Rychly (eds.), Labour Administration in Uncertain Times: Policy, Practice and Institutions Since the Crisis, Cheltenham: Edward Elgar Publishing, 194-221.

Zehavi, A. (2012) 'Welfare state politics in privatization of delivery: linking program constituencies to left and right', Comparative Political Studies, 45, 2, 194-219.

Zeitlin, J. (2009) 'The Open Method of Coordination and reform of national social and employment policies', in M. Heidenreich and J. Zeitlin (eds.), Changing European Employment and Welfare Regimes: The Influence of the Open Method of Coordination on National Reforms, London/New York: Routledge, 214-45. 